scientific trials. Though this may explain the mechanism of action of anabolic steroids in athletes, these results and the assumptions within this hypothesis require further investigation.

We thank Dr J A Davies, Professor C C Bird, Professor D Johnston, Mr N Williams, and Mr J Primrose for their encouragement and for help in obtaining biopsy specimens; Peter Walsh and Elizabeth Wakefield for technical help; and Sterling Research for financial help.
1 Sue-Ling HM, Hosegood JL, Johnston D, McMahon MJ, Davies JA. Comparison of oral stanozolol with low dose heparin in prevention of deep venous thrombosis in high risk patients after elective major abdominal surgery. Fibrinolysis 1988;2:37-41.

2 Dubowitz V. Muscle biopsy: a practical approach. 2nd ed. London: Baillière Tindall, 1985.

3 Larsson L, Ansved T. Effects of long-term physical training and detraining on enzyme histochemical and functional skeletal muscle characteristics in man. Muscle Nerve 1985;8:714-22.

4 Saltin B, Henriksson J, Nygaard E, Andersen P, Jansson E. Fibre types and metabolic potentials of skeletal muscles in sedentary man and endurance runners. Ann NY Acad Sci 1977; 301:3-29.

(Accepted 27 fune 1988)

\section{Allergy to latex gloves: unusual complication during delivery}

\author{
K Turjanmaa, T Reunala, R Tuimala, \\ T Kärkkäinen
}

Department of Clinical Sciences, University of Tampere, Tampere, Finland

K Turjanmaa, MD, senior lecturer

T Reunala, MD, associate professor

\section{Department of Obstetrics} and Gynaecology,

University Central Hospital

Tampere, Tampere

$\mathrm{R}$ Tuimala, MD, senior

lecturer

University Central Hospital

Helsinki, Hospital for

Allergic Diseases, Helsinki

T Kärkkäinen, PHD, chemist

Correspondence to: Dr K Turjanmaa, Department of Dermatology, University Central Hospital Tampere, SF-33520 Tampere, Finland.
Several drugs cause anaphylactic reactions during anaesthesia, including barbiturate induction agents and muscle relaxants such as suxamethonium.' Anaphylactic reactions to drugs such as propanidid and oxytocin during caesarean section have been reported. ${ }^{12}$ We describe four women who developed systemic allergic reactions during delivery; the allergen was latex that eluted from surgical gloves worn by the obstetrician.

\section{Case reports}

All four patients had previously experienced local wheal and flare reactions when using latex gloves. The first patient, a nurse, had an anaphylactic reaction during her first delivery, which was performed by caesarean section, and anaesthetic drugs were suspected to be the cause. Her second delivery was vaginal, and she developed generalised cutaneous symptoms immediately after ventouse delivery. The patient was convinced that the surgeon's gloves had caused her symptoms. This was confirmed by a prick test and radioallergosorbent test for latex. ${ }^{3}$ Thereafter she had two uneventful deliveries, in which oxytocin and ergometrine maleate were used and the staff wore only polyvinyl chloride gloves.

Allergy to latex was diagnosed in our second patient, a surgeon, before her first delivery. Despite this an allergic reaction after stitching of the episiotomy wound was a surprise both to her and to the obstetrician. During her next two deliveries latex gloves were not used, but during her third delivery she developed contact urticaria after having a rubber cuff on her arm.

In the other patients, a dentist and a secretary, the symptoms developed immediately after stitching of the episiotomy wound but an allergic reaction was not diagnosed. In the dentist an intradermal test for allergy to lignocaine was performed but the result was negative. ${ }^{\prime}$

All patients were treated with intravenous hydrocortisone or methylprednisolone, and the first patient received adrenaline as well because of severe hypotonia and bronchospasm under general anaesthesia. They all recovered quickly, but their urticaria lasted for up to 18 hours.

All of the women had a history of atopic dermatitis and gave at least one positive reaction to common inhaled allergens on routine prick testing. Three of them had allergic rhinitis and one extrinsic asthma. Prick tests from several brands of gloves gave strongly positive reactions (bigger than those to histamine), and radioallergosorbent tests for latex showed raised titres of specific IgE. A Prausnitz-Küstner test with serum from our first patient gave positive results in two healthy recipients.

\section{Comment}

During the past 10 years several reports have shown that latex eluting from surgical or cleaning gloves can sensitise people and cause local contact urticaria. ${ }^{34}$ The frequency of this allergy among doctors and nurses in the operating unit at University Central Hospital, Tampere, was $6.4 \% .^{3}$ This study, and one other, show that people with the allergy may be at risk during delivery, operations, and even vaginal examination. In addition to medical staff, people sensitised after wearing cleaning gloves made from latex may also be at risk, as in one of our patients. Surgical and cleaning gloves both contain latex allergen, but the amount of protein eluting from these gloves varies.

People who are allergic to latex are generally atopic, tend to be women, and have a history of irritation from wearing gloves. Prick testing with glove allergen will confirm the diagnosis, and many, though not all, people allergic to latex yield positive results to the radioallergosorbent test for latex, which is now commercially available. ${ }^{3}$ Patients should be informed of their allergy, and during operations or deliveries staff should use non-latex gloves - that is, gloves made from polyvinyl chloride or synthetic rubber. ${ }^{4}$ Rubber masks, tubes, and cuffs should also be avoided.

\footnotetext{
I Stoelting RK. Allergic reactions during anesthesia. Anesth Analg 1983;62: $341-56$.

2 Slater RM, Bowles BJM, Pumphrey RSH. Anaphylactoid reaction to oxytocin in pregnancy. Anaesthesia 1985;40:655-6.

Turjanmaa K, Reunala T. Contact urticaria from rubber gloves. Dermatol Clin $1988 ; 6: 47-51$.

4 Turjanmaa K, Laurila K, Mäkinen-Kiljunen S, Reunala T. Rubber contact urticaria. Allergenic properties of 19 brands of latex gloves. Contact Dermatitis (in press).

5 Axelsson JGK, Johansson SGO, Wrangsiö K. IgE-mediated anaphylactoid reactions to rubber. Allergy 1987;42:46-50.

(Accepted 13 fuly 1988)
}

\section{Correction}

Maternal serum screening for Down's syndrome in early pregnancy

A printer's error occurred in the authors' footnote of this paper by Professor Nicholas J Wald and others ( 8 October, p 883). Howard S Cuckle is CRC senior lecturer and not CRC technical lecturer as published. 